flexibility you provide to the model, the more broadly you can cast your net," said Miralles.

Janssen is a unit of J\&J.

\title{
Hands-off incubator
}

\section{By Chris Cain, Staff Writer}

Johnson \& Johnson has announced a life sciences incubator that, unlike earlier incubators started by biopharmas such as Biogen Idec Inc. and Pfizer Inc., provides no funding and receives no IP rights from occupants of the space. Instead, J\&J hopes to spark informal connections that could lead to more deal opportunities down the road.

J\&J is converting 30,000 square feet of unused space on its La Jolla research campus into Janssen Labs, which the pharma hopes will house up to 18-20 life science companies. The companies will pay rent, and J\&J will otherwise be completely hands off. The center is expected to open in early 2012.

Diego Miralles, head of Janssen Healthcare Innovation and the West Coast Research Center for the Johnson \& Johnson Research

"We wanted to make the proposition more flexible and did not want to limit entrepreneurs who might not want to come if our investment was required. The more flexibility you provide to the model, the more broadly you can cast your net."

-Diego Miralles, Johnson \& Johnson
\& Development LLC where Janssen Labs is housed, told SciBX the approach is intended to attract companies that are not necessarily looking for a partnership agreement.

"We separated the funding from the space based on our review of what worked and did not work in other models. We wanted to make the proposition more flexible and did not want to limit entrepreneurs who might not want to come if our investment was required. The more

\section{Options, options, options}

In 2007, Biogen Idec and Pfizer created incubators in which both space and funding were provided to startup occupants. Both incubators have since been shuttered (see Box 1, "Incubators no more").

Jay Lichter, a managing director at Avalon Ventures, told SciBX that Janssen's model provides clear advantages over prior companysponsored incubators, in which "a startup would give up a two-year option to license their technology for a small amount of money and space. I would never do that deal," he said.

He added that once a company was in the incubator for a couple of years, "if the tech wasn't licensed, the company was tainted. It could be totally unrelated to the promise of the company; someone just decided to stop focusing in a particular therapeutic area."

At Janssen Labs, companies will sign renewable short-term lease agreements for modular space and will have access to shared complex equipment such as mass spectrometers and NMR machines. Miralles noted the site also serves as a research hub for J\&J, and as a result companies can leverage existing processes at the site such as bulk purchasing and waste disposal.

Lichter said these shared benefits should not be underestimated. Indeed, Avalon runs its San Diego-based companies in a similar manner. The venture group leases about 10,000 square feet of space in a facility in which it houses 5-6 of its early stage companies.

\section{Box 1. Incubators no more.}

In 2007, Pfizer Inc. and Biogen Idec Inc. created incubators that provided both space and funding for startups.

The Biogen Idec Innovation Incubator funded and housed two companies: Escoublac Inc. and Provasculon Inc.

Biogen Idec spokesperson Naomi Aoki said the incubator is now closed and that the company is "continuing to rethink its incubator strategy." Escoublac was developing osteocalcin technology from Columbia University. The biotech shut down in the fall of 2010, and Columbia repartnered the technology with Sanofi earlier this year. ${ }^{1}$

Cardiovascular company Provasculon is still being supported by Biogen but is no longer in the physical incubator. "We are still working to help to meet their business goals and business plan. They are a cardiovascular-focused company, which is not a strategic area we are focused on," said Aoki.

The Pfizer Incubator in La Jolla supported three companies: Wintherix LLC, Fabrus LLC and RGo BioScience LLC. Wintherix and Fabrus left the incubator without granting Pfizer rights to any programs, although Pfizer retains equity in the companies. A Pfizer spokesperson confirmed to SciBX that RGo BioScience has been acquired by Pfizer and that the incubator space has been up for sale since November 2008.

Wintherix is developing activators of the wingless-type MMTV integration site (WNT) signaling pathway to promote bone growth. ${ }^{2}$ The biotech has since spun out a related company, Epitherix, which is developing WNT inhibitors for cancer. ${ }^{3}$ Fabrus, which is building libraries for antibody discovery, ${ }^{4}$ has funding from Opko Health Inc. 
"One secretary for everybody, combined purchasing, it's very convenient," he told SciBX. "Because they are all Avalon companies where we are the sole investor, there is no real conflict."

He added: "The J\&J space is very useful for San Diego companies that aren't in a situation like Avalon companies. This would be the first space like this in San Diego." He said the prime beneficiaries will likely be startups out of local institutions with seed money from friends and family.

"What I like about the J\&J offering is that it not only provides space but it provides space in the middle of our most concentrated life sciences geography, up in Torrey Pines," said BIOCOM president and CEO Joseph Panetta. "There is plenty of lab space available in San Diego, but the advantage this brings is that it is located within a facility with much more sophisticated resources in hand."

$\mathrm{BIOCOM}$ is a trade association representing life sciences companies in southern California.

Paul Laikind, CBO and SVP of business development at the SanfordBurnham Medical Research Institute, told SciBX, "I think this model is refreshing. Janssen spent a lot of time looking at the pros and cons of other incubators, and that they've decided to do this without strings attached shows they care a lot about the ecosystem they operate in, and it will benefit them in the long run."

He added, "They might not have contractual access to these companies, but they'll have preferred access-they'll be right next door."

Both Panetta and Laikind noted that lab space is widely available in San Diego and emphasized that space alone does not make an incubator-it is the concentration of resources that is key.

Sanford-Burnham is in the final stages of planning its own incubator at its La Jolla campus, which Laikind says will launch in the next few months. The space will be open to researchers at Sanford-Burnham and the University of California, San Diego, and it will provide access to lab and office space as well as use of the campus' 33 core facilities. The UCSD Rady School of Management and Connect's Springboard program will provide business advice to the early stage companies. Connect is a San Diego-based not-for-profit that promotes the commercialization of local science.

"It's one of the reasons we're excited about the Janssen Labs being right on our doorstep. We could feed into them as small companies start out in our space, apply for SBIR [Small Business Innovation Research] grants and additional funding, and grow out of our space," said Laikind.

He pointed to the California Institute for Quantitative Biosciences (QB3) incubator at the University of California, San Francisco as a model for the Sanford-Burnham incubator. Last week, J\&J's Corporate Office of Science and Technology announced a partnership with QB3 to fund an existing grant program, Bridging-the-Gap, aimed at transitioning early stage companies from NIH grant funding to SBIR funding. Neena Kadaba, director of industrial alliances at QB3, told $S c i B X$ that at least three prior Bridging-the-Gap awardees are current tenants of the QB3 incubator and others have gone on to successful corporate partnerships.

\section{Managing incubation}

To run the San Diego incubator, J\&J has contracted with Prescience International, a management firm that in 2004 founded the San Jose BioCenter, an incubator for life sciences, nanotech and cleantech companies.

"Our goal is to make it as quick and affordable as possible to start a life science company," said Melinda Richter, founder and CEO of Prescience. "We operate like a professional management firm for these companies by ensuring they have the correct licenses and permits to get them up and running and operating according to code. We also provide safety training and all of the resources you would need to have in a big company."

Unlike at the San Jose BioCenter, where Prescience is in charge, J\&J will have the final say on which companies enter Janssen Labs. There are subjective criteria the pharma Johnson \& Johnson will take into account in making its decisions. For example, would-be entrants must be working in an area of significant medical or market need, have a compelling science or technology, have a credible scientific team and be able to meet their financial obligations.

Miralles noted that Johnson \& Johnson Development Corp., the company's venture arm, is separate from this initiative. "We are agnostic to venture investment from J\&J. If it works out for the company and our venture group that's great; if it doesn't work out, that's great too," he said. However, he added, "We hope that this project will help us generate having good will associated with San Diego and the biotech community, and that, in turn, could help us establish a relationship with these companies residing in our home."

Cain, C. SciBX 4(43); doi:10.1038/scibx.2011.1196

Published online Nov. 3, 2011

\section{REFERENCES}

1. Cain, C. SciBX 4(15); doi:10.1038/scibx.2011.417

2. McCallister, E. BioCentury 18(45), A12; Oct. 11, 2010

3. McCallister, E. BioCentury 18(49), A14; Nov. 8, 2010

4. Lou, K.-J. SciBX 3(44); doi:10.1038/scibx.2010.1314

\section{COMPANIES AND INSTITUTIONS MENTIONED}

Avalon Ventures, La Jolla, Calif.

Biogen Idec Inc. (NASDAQ:BIIB), Weston, Mass.

BIOCOM, San Diego, Calif.

California Institute for Quantitative Biosciences, San Francisco, Calif.

Columbia University, New York, N.Y.

Connect, San Diego, Calif.

Fabrus LLC, La Jolla, Calif.

Johnson \& Johnson (NYSE:JNJ), New Brunswick, N.J.

Johnson \& Johnson Development Corp., New Brunswick, N.J.

Opko Health Inc. (NYSE:OPK), Miami, Fla.

Pfizer Inc. (NYSE:PFE), New York, N.Y.

Prescience International, San Francisco, Calif.

Provasculon Inc., Cambridge, Mass.

RGo BioScience LLC, San Diego, Calif.

Sanford-Burnham Medical Research Institute, La Jolla, Calif.

Sanofi (Euronext:SAN; NYSE:SNY), Paris, France

University of California, San Diego, La Jolla, Calif.

University of California, San Francisco, Calif.

Wintherix LLC, San Diego, Calif. 